\title{
A Century and Half of Hydrogeomorphological Disasters in Mainland Portugal
}

\author{
José L. Zêzere, Susana S. Pereira, and Pedro P. Santos
}

\section{Abstract}

The Disaster database lists disastrous floods and landslides registered in mainland Portugal in the period 18652015, based on data collected from newspapers. The database includes 1950 hydrogeomorphological disaster cases that caused 1256 deaths, 14,884 evacuated people and 41,977 displaced people. Disastrous floods are clustered in the Lisbon region and the Tagus valley, in the Oporto region and the Douro valley, in the Coimbra region and the Mondego valley and along the Vouga valley. Disastrous landslides are clustered in the Lisbon region and the Douro valley. The period 1935-1969 registered the highest number of disastrous floods and landslides, whereas the last 45 years of the series (19702015) do not show any clear temporal trend. However, the 10 -year moving average increased at the beginning of the twenty-first century, for floods and landslides, and it is apparent the increasing number of disaster events consisting of several cases, which may result from the increasing occurrence of rainfall extreme events related with climate change. The spatial and temporal trends observed on disastrous floods and landslides reflect the distribution of conditioning factors, the temporal incidence of triggering factors, but also the evolution of the exposure and the vulnerability of people, structures and infrastructures.

\section{Keywords}

Floods • Landslides • Disasters - Database •

Mainland Portugal

\section{Introduction}

Hydrogeomorphologic disasters are natural processes of hydrologic (flood, flash flood, urban flood) or geomorphologic (landslides and other slope mass movements) origin that produced harmful consequences like loss of life or injury, property damage, economic disruption or environmental degradation (Zêzere et al. 2014).

According to several sources (e.g. EM-DAT 2019), hydrogemorphological disasters registered an increasing trend during last decades worldwide, which has been related to the increasing frequency of meteorological extreme events associated to climate changes (IPCC 2012), but also to the population growth and the increasing exposure of people and assets (Zêzere 2007).

In this work, we present the Disaster database that lists disastrous floods and landslides registered in mainland Portugal for a long-lasting period (151 years).

\section{Materials and Methods}

The Disaster database contains both disaster cases and disaster events. A Disaster case is a unique location that was affected by a flood or landslide in a specific period of time, which generated fatalities, injuries or missing, evacuated or displaced people, independently of the number of affected people. A Disaster event is a set of Disaster cases sharing the same trigger, which can have a widespread spatial extension and a certain magnitude (Zêzere et al. 2014).

The information on hydrogeomorphological disasters was collected systematically by analyzing newspapers. We assume that, as a rule, the newspapers report those floods and landslides that generated human consequences in Portugal. A total of 17 newspaper titles were used to guarantee the largest temporal coverage, but also the best regional spatial distribution of the newspapers to cover the complete study area. For the period 1865-1907 only up to two 
newspapers were available, whereas the number of newspapers increases to four for the period 1907-1936. For the period 1936-2015 the number of surveyed newspaper ranges from nine to twelve.

Statistical tests have shown that the Disaster database can be considered complete for the period 1936-2015, whereas the incompleteness can be up to $42 \%$ for the period 1865 1935 (Zêzere et al. 2014).

\section{Results and Discussion}

The Disaster database includes 1950 hydrogeomorphological disaster cases (on average, 13 per year) that caused 1256 deaths, 14,884 evacuated people and 41,977 displaced people (Table 1). Most disasters were generated by floods (85\%) that were responsible for $81 \%$ of total deaths, $94.5 \%$ of total evacuated people and $96.2 \%$ of total displaced people.
The geography of disastrous floods and landslides is shown in Fig. 1. Although widespread all over the country, disastrous flood cases are clustered in the Lisbon region and the Tagus valley, in the Oporto region and the Douro valley, in the Coimbra region and the Mondego valley and along the Vouga valley. On the contrary, landslides are typically constrained to the region located northward the Tagus valley, in association with the steepest slopes. The Lisbon region and the Douro valley are the most important clusters of landslide cases.

The yearly distribution of disastrous floods and landslides registered in mainland Portugal in the period 1865-2015 is shown in Fig. 2. The 10-year moving average is represented by the blue and red lines, for floods and landslides, respectively.

The first 70 years of the series (1865-1934) were characterized by a low incidence of floods and landslides generating adverse human consequences. During this period, the year 1909 was an outlier, associated to a single extreme

Table 1 Hydrogeomorphological disaster cases and their human consequences in mainland Portugal in the period 1865-2015

\begin{tabular}{l|l|l|l}
\hline & Floods & Landslides & Total \\
\hline Number of cases & 1658 & 292 & 1950 \\
\hline Number of deaths & 1015 & 241 & 1256 \\
\hline Number of missing people & 71 & 23 & 94 \\
\hline Number of injured people & 479 & 433 & 912 \\
\hline Number of evacuated people & 14,061 & 823 & 14,884 \\
\hline Number of displaced people & 40,365 & 1612 & 41,977
\end{tabular}

Fig. 1 Spatial distribution of disastrous floods (left) and landslides (right) occurred in mainland Portugal in the period 1865-2015
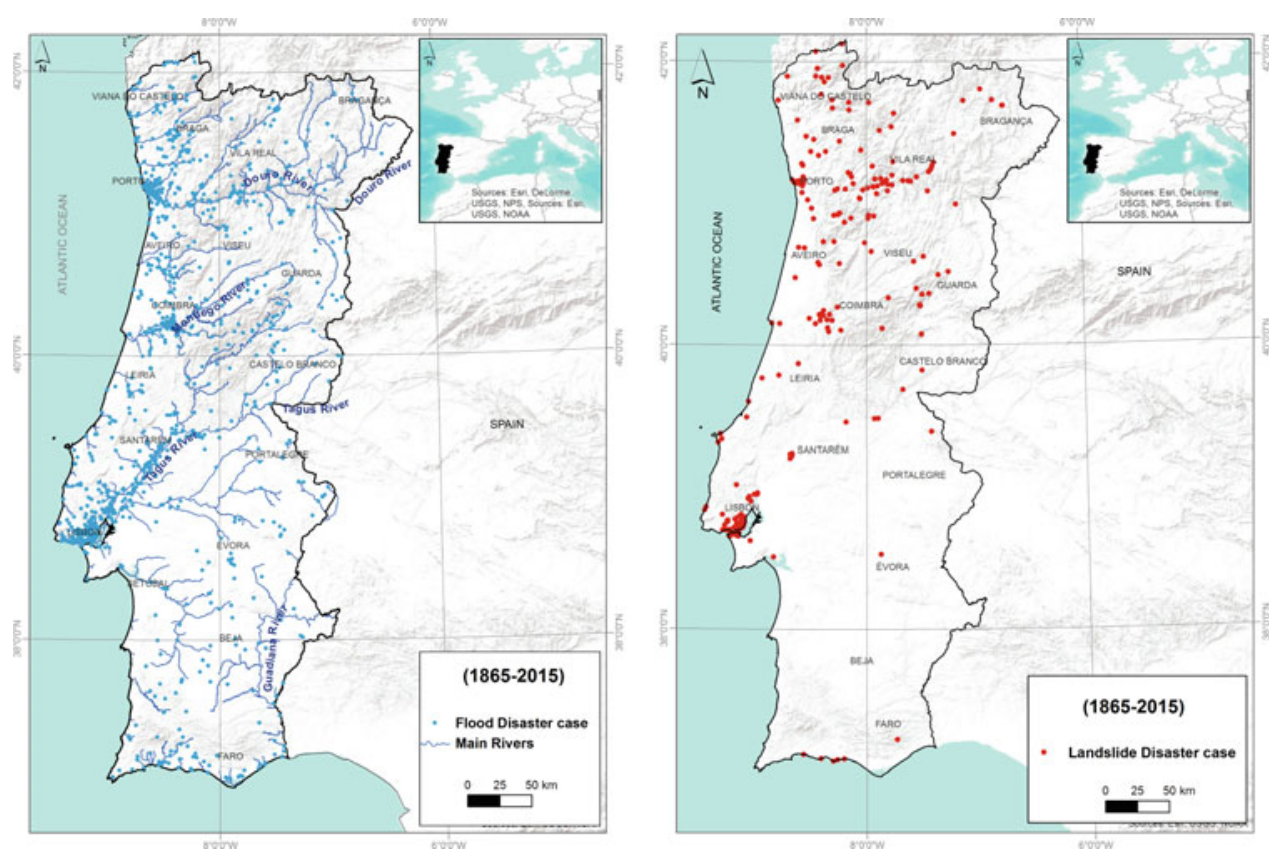


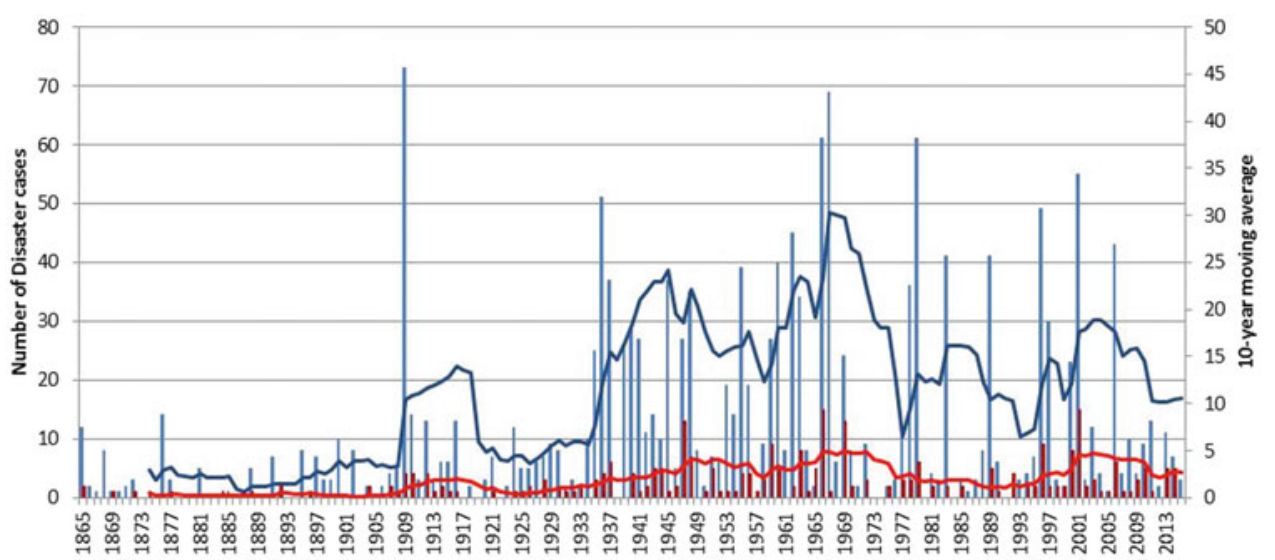

Floods $\quad$ Landslides -10-year moving average (floods) - $\quad$ 10-year moving average (landslides)

Fig. 2 Temporal distribution of disastrous floods and landslides occurred in mainland Portugal in the period 1865-2015

event occurred in December that affected the north and centre of Portugal. This event ranks the 2nd place in the top hydrogeomorphological disasters (Table 2) because it contains the highest number of flood and landslide cases in the Disaster database and generated 34 death people (Pereira et al. 2016).

The 35-year period lasting from 1935 to 1969 registered the highest number of disastrous floods $(781,47 \%$ of total flood cases) and landslides (133, 46\% of total landslide cases). As a consequence, the 10-year moving average raised up to 30 and 5 at the end of the 1960 decade, for floods and landslides, respectively. This period includes the most catastrophic hydrogeomorphological disaster ever registered in mainland Portugal (Table 1), the flash flood affecting the Lisbon region in 25-26 November 1967 that killed more than 500 people (Trigo et al. 2016).

Table 2 Top 10 hydrogeomorphological disaster events occurred in mainland Portugal in the period 1865-2015

\begin{tabular}{|c|c|c|c|c|c|c|c|c|c|}
\hline Rank & $\begin{array}{l}\text { Event } \\
\text { type }\end{array}$ & Date & Affected districts & $\begin{array}{l}\text { Event } \\
\text { duration } \\
\text { (days) }\end{array}$ & $\begin{array}{l}\text { \#Disaster } \\
\text { cases }\end{array}$ & Fatalities & $\begin{array}{l}\text { Injured } \\
\text { people }\end{array}$ & $\begin{array}{l}\text { Evacuated } \\
\text { people }\end{array}$ & $\begin{array}{l}\text { Displaced } \\
\text { people }\end{array}$ \\
\hline 1 & FF; UF & $\begin{array}{l}25-26 \mathrm{Nov} \\
1967\end{array}$ & 11,15 & 2 & 67 & 522 & 330 & 304 & 885 \\
\hline 2 & $\begin{array}{l}\text { F; FF; } \\
\text { UF; L }\end{array}$ & $\begin{array}{l}20-28 \mathrm{Dec} \\
1909\end{array}$ & $\begin{array}{l}1,3,4,5,6,9,10,11,13,14 \\
15,16,17,18\end{array}$ & 9 & 83 & 37 & 4 & 679 & 478 \\
\hline 3 & $\mathrm{~F} ; \mathrm{FF}$ & $\begin{array}{l}15-17 \text { Feb } \\
1941\end{array}$ & 11,15 & 3 & 6 & 33 & 0 & 109 & 0 \\
\hline 4 & F; L & $\begin{array}{l}9-12 \text { Feb } \\
1904\end{array}$ & $1,3,13,17$ & 4 & 4 & 27 & 1 & 1 & 3 \\
\hline 5 & $\mathrm{~F} ; \mathrm{FF}$ & $\begin{array}{l}25-26 \text { Nov } \\
1865\end{array}$ & 11 & 2 & 9 & 21 & 0 & 0 & 0 \\
\hline 6 & $\begin{array}{l}\text { FF; UF; } \\
\text { L }\end{array}$ & $\begin{array}{l}18-19 \text { Nov } \\
1983\end{array}$ & 11,14 & 2 & 37 & 18 & 0 & 255 & 3239 \\
\hline 7 & FF; UF & $\begin{array}{l}\text { 2-9 Nov } \\
1997\end{array}$ & $2,8,14,15$ & 8 & 16 & 11 & 22 & 141 & 134 \\
\hline 8 & F; FF; L & $\begin{array}{l}5-16 \text { Feb } \\
1979\end{array}$ & $5,6,11,13,14,17$ & 12 & 67 & 8 & 3 & 4244 & 14,322 \\
\hline 9 & F; UF; L & $\begin{array}{l}\text { 2-6 Jan } \\
1940\end{array}$ & $4,7,11,14,15,17$ & 5 & 26 & 7 & 3 & 35 & 1043 \\
\hline 10 & $\mathrm{~F} ; \mathrm{L}$ & $\begin{array}{l}\text { 26-27 Jan } \\
2001\end{array}$ & $1,3,6,9,10,13,17,18$ & 2 & 28 & 6 & 5 & 402 & 570 \\
\hline
\end{tabular}

Event type: F (flood); FF (flash flood); UF (urban flood); L (landslide)

Districts: 1-Aveiro; 2-Beja; 3-Braga; 4-Bragança; 5-Castelo Branco; 6-Coimbra; 7-Évora; 8-Faro; 9-Guarda; 10-Leiria; 11-Lisboa; 12-Portalegre; 13-Porto; 14-Santarém; 15-Setúbal; 16-Viana do Castelo; 17—Vila Real; 18—Viseu 
The last 45 years of the series (1970-2015) do not show any clear temporal trend, although the 10-year moving average increased at the beginning of the twenty-first century, for both flood and landslide cases. Moreover, it is remarkable that the annual number of 40 flood cases was reached 6 times after 1978, whereas that value was exceeded in just 5 years in the complete previous period (1865-1978). The increasing number of disaster events consisting of several cases may be related with the increasing occurrence of rainfall extreme events related with climate change, but additional work is needed to demonstrate such relationship in the study area.

The seasonality of disastrous floods and landslides occurred in mainland Portugal is shown in Fig. 3. As it was expected, hydrogeomorphological events are uncommon during the driest period, from April to September. Floods are more frequent from November to February (75\% of total flood cases), whereas landslides commonly occur from December to March (73\% of total landslide cases). Flash floods and urban floods occur usually during the autumn and the early winter, in response to very intense rainfall events typically concentrated in just a few hours (Zêzere et al. 2014; Trigo et al. 2016). On the contrary, landslides are more common latter on the hydrologic year, being triggered by the rise of groundwater table, which is usually related to persistent rainfall periods lasting from several weeks to a few months (Zêzere et al. 2014). Such rainfall conditions are usually also responsible for floods along the major rivers (e.g. Tagus, Douro, Mondego).

The top 10 hydrogeomorphological disaster events occurred in mainland Portugal in the period 1865-2015 are summarized in Table 2 (Pereira et al. 2018). Besides the already mentioned 1967 and 1909 events that rank first and second, other relevant events were identified, most of them

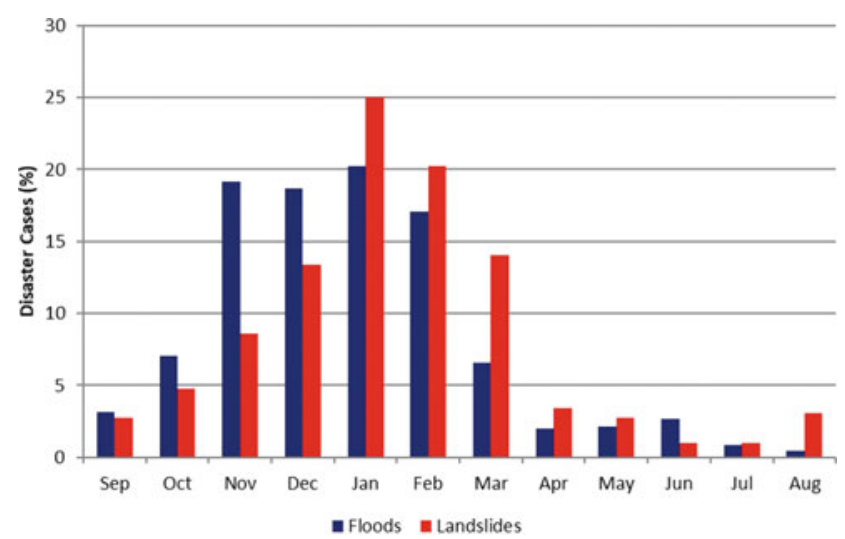

Fig. 3 Monthly distribution of disastrous floods and landslides occurred in mainland Portugal in the period 1865-2015 occurred during the twentieth century. The single top event occurred in the twenty-first century is the January 2001 event that ranks the 10th position in the global disaster list.

\section{Concluding Remarks}

The Disaster database lists those hydrogeomorphological cases that generated human consequences in mainland Portugal during a period lasting more than 150 years. The spatial and temporal trends observed on disastrous floods and landslides reflect the distribution of conditioning factors, the temporal incidence of triggering factors, but also the evolution of the exposure and the vulnerability of people, structures and infrastructures. Therefore, this database allows for the knowledge of the disaster drivers and their distinct incidence both in time and in space, which should be considered by stakeholders responsible for civil protection and spatial planning in order to manage and reduce disaster risk.

Acknowledgements This work was financed by national funds through FCT-Portuguese Foundation for Science and Technology, I.P., under the framework of the project FORLAND-Hydrogeomorphologic risk in Portugal: driving forces and application for land use planning [PTDC/ATPGEO/1660/2014].

\section{References}

EM-DAT (2019) The OFDA/CRED International disaster databasewww.emdat.be-Université Catholique de Louvain, Brussels, Belgium. Last accessed 23 Mar 2019

IPCC (2012) Managing the risks of extreme events and disasters to advance climate change adaptation. A special report of working groups I and II of the intergovernmental panel on climate change. Cambridge University Press, Cambridge, UK, and New York, NY, USA

Pereira S, Ramos AM, Zêzere JL, Trigo RM, Vaquero JM (2016) Spatial impact and triggering conditions of the exceptional hydro-geomorphological event of December 1909 in Iberia. Nat Hazards Earth Syst Sci 16:371-390

Pereira S, Ramos AM, Rebelo L, Trigo RM, Zêzere JL (2018) A centennial catalogue of hydro-geomorphological events and their atmospheric forcing. Adv Water Resour 122:98-112

Trigo R, Ramos C, Pereira S, Ramos A, Zêzere JL (2016) The deadliest storm of the 20th century striking Portugal: flood impacts and atmospheric circulation. J Hydrol 541(A):597-610

Zêzere JL (2007) Riscos e Ordenamento do Território. Inforgeo 20 (21):59-63

Zêzere JL, Pereira S, Tavares AO, Bateira C, Trigo RM, Quaresma I, Santos PP, Santos M, Verde J (2014) DISASTER: a GIS database on hydro-geomorphologic disasters in Portugal. Nat Hazards 72:503-532 